\title{
Blood flow in the ovaries and ovarian follicles of Romanov and Préalpes-du-Sud ewes
}

\author{
B. W. Brown* and M. A. Driancourt \\ I.N.R.A., Station de Physiologie de la Reproduction, 37380 Nouzilly, France
}

\begin{abstract}
Summary. Radioactive microspheres ( $15 \mu \mathrm{m}$ diameter) were used to measure capillary blood flow rates in the ovaries and ovarian follicles $\left(Q_{f}\right)$ in high fecund Romanov and low fecund Préalpes-du-Sud ewes at the preovulatory stage of the oestrous cycle. Additionally, assessments of the percentage of arterial blood passing through ovarian arterio-venous anastomoses were obtained.

The mean \pm s.e.m. $Q_{f}$ per unit volume of theca $\left((\mathrm{ml} / \mathrm{min}) \times 10^{4} / \mathrm{mm}^{3}\right)$ for non-atretic follicles in Romanov ewes was significantly greater $(P<0.05)$ than that in Préalpes ewes $(365 \cdot 8 \pm 42 \cdot 4, n=19$, compared with $241 \cdot 3 \pm 30 \cdot 1, n=14)$. For each breed, the mean $Q_{f}$ value for non-atretic follicles was 8-10 times greater than that for atretic follicles.

In Romanov ewes, total $\mathrm{Q}_{\mathrm{f}}\left((\mathrm{ml} / \mathrm{min}) \times 10^{4}\right)$ and $\mathrm{Q}_{\mathrm{f}}$ per unit volume of theca was greatest in small-sized follicles $(3 \cdot 1-5.0 \mathrm{~mm})$ while in Préalpes ewes, maximum flow was attained in larger-sized follicles $(5 \cdot 1-7 \cdot 0 \mathrm{~mm})$. The elevated $Q_{f}$ in small-sized follicles in Romanov ewes may be conducive to more follicles achieving maturation at a smaller diameter in this breed than occurs in the Préalpes ewes.

The absence of flow through ovarian arterio-venous anastomoses in the Romanov, but not in the Préalpes, ewes suggests different mechanisms for controlling the distribution of the total ovarian blood supply in the 2 breeds.
\end{abstract}

Keywords: follicles; blood flow; sheep; prolificacy

\section{Introduction}

Many studies have been performed in attempts to explain why sheep of some breeds produce more ovulations than others (Scaramuzzi \& Radford, 1983; Bindon, 1984; Driancourt et al., 1988). Comparative studies of hormone concentrations in ewes of high and low fecundity (Land et al., 1973; Cahill et al., 1981; Baird et al., 1982; Scaramuzzi \& Radford, 1983; Bindon, 1984) indicate that the plasma concentrations of $\mathbf{L H}$, oestradiol or progesterone did not differ substantially. In contrast, conflicting results have been reported for FSH concentrations in such ewes. Compared with single ovulating breeds, some prolific breeds of sheep (Booroola and D'Man) have significantly higher FSH concentrations (Lahlou-Kassi et al., 1984; Bindon et al., 1985; McNatty et al., 1987), while others exhibit only marginally higher FSH levels (Romanov: Cahill et al., 1981) or no increase at all (Finn sheep: Webb \& England, 1982). Furthermore, studies with hypophysectomized Booroola and Romanov ewes (Driancourt et al., 1988; Fry et al., 1988) have suggested that the higher FSH plasma concentrations are not causally associated with higher ovulation rate.

However, an assessment of the effect of gonadotrophins on ovulation rate cannot be restricted merely to plasma concentrations of the hormone and must include consideration of the actual amount of the hormone that is delivered to the ovary and follicles via the vasculature. Carson $e t$

*Present address: C.S.I.R.O., Division of Animal Production, P.O. Box 239, Blacktown, New South Wales 2148, Australia. 
al. (1986) showed that the amount of LH delivered to rat follicles, compared to circulating values of the hormone, was limited and changed with follicle maturation. Two circumstances could contribute to a more efficient utilization of the ovarian blood supply in prolific breeds of sheep, thereby enhancing the amount of gonadotrophin delivered to the ovary and ovarian follicles; a greater follicular capillary blood flow rate, as demonstrated for Booroola Merino compared with non-Booroola Merino ewes (Brown et al., 1981) and a lack of ovarian arterio-venous shunting of blood away from the ovarian capillary beds, a mechanism prevailing in ovaries of single ovulating Merinos (Mattner et al., 1981).

To investigate whether such elevated follicular blood flows occur in other high ovulating breeds of sheep, capillary blood flow rates were measured (using radioactive microspheres) in ovarian follicles in Romanov ewes, at the preovulatory stage, and the values compared with corresponding estimates obtained in low ovulating Préalpes ewes. In addition, estimates of the proportion of flow passing through the ovarian arterio-venous anastomoses were made in the two breeds.

\section{Materials and Methods}

Animals. Five Préalpes-du-Sud and 4 Romanov ewes aged 2-3 years and weighing $42-50 \mathrm{~kg}$ were used at Nouzilly, France, early in the breeding season during September and October. The ewes were housed indoors in a group pen, under conditions of natural daylight and temperature, for many months before the experiment and were fed lucerne hay and chaff ad libitum. Water was always available.

A progesterone sponge ( $40 \mathrm{mg}$ fluorogestone: Intervet, Angers, France) was inserted into the vagina of each ewe and left in place for 2 weeks to synchronize the ovarian cycles. The sponges were removed immediately after the cannulation procedure, $36-40 \mathrm{~h}$ before blood flow measurement. Pre-treatment of ewes with progesterone only, has no effect on ovarian capillary blood flow (Brown \& Mattner, 1984).

Surgical preparation of the animals. With the ewes under halothane-maintained anaesthesia, polyethylene catheters (1.0 mm i.d., $1.5 \mathrm{~mm}$ o.d.: Dural Plastics and Engineering, Dural, New South Wales, Australia) filled with heparin saline (1000 i.u. $/ \mathrm{ml} 0.9 \%(\mathrm{w} / \mathrm{v}) \mathrm{NaCl})$ were inserted into (a) the left ventricle via the left carotid artery for injection of the microsphere dose and (b) a femoral artery via a saphenous artery for obtaining an arterial reference sample for determination of blood flows.

The genital tract was exposed through a mid-abdominal incision, and an expanded polyethylene catheter (minor i.d. $0.5 \mathrm{~mm}$, o.d. $1.0 \mathrm{~mm}$; major i.d. $1.0 \mathrm{~mm}$, o.d. $1.5 \mathrm{~mm}$ ), filled with heparin saline, was inserted into the lumen of a side branch of one ovarian artery and held in position with fine ligatures. This arteriole branch originated immediately distal to the ovarian vascular pedicle and was associated with the artery supplying the ovary containing the largest follicle(s). After all other obvious side branches of this ovarian artery were ligated, a solution of Evans' Blue in plasma (sufficient in concentration to give a visible interface with blood) was injected through this catheter to ensure that infusates administered via this route would pass directly to the ipsilateral ovary.

To ensure that the ovary associated with the side branch catheterization would contain preovulatory follicle(s) at slaughter, the contralateral ovary was excised. Unilateral ovariectomy in ewes as late as Day 14 of the oestrous cycle does not alter normal ovulation rate (Findlay \& Cummings, 1977). All catheters were then re-filled with heparin saline and, after the side-branch catheter was exteriorized through a stab wound in the flank, the abdomen was closed and the animals allowed to recover.

Assessment of blood flow rates in ovaries and follicles. The method of fractionation the cardiac output using radioactive microspheres as the indicator (Brown et al., 1974; Hales, 1974), was used to obtain measures of capillary blood flow in ovaries and ovarian follicles around the expected time of ovulation (i.e. $36-40 \mathrm{~h}$ after sponge removal). When used in sheep, large ventricular doses of microspheres $\left(10-15 \times 10^{6}\right)$ are required in order that tissues with low blood flow rates (such as the ovarian stroma) entrap sufficient numbers of microspheres to provide accurate measures of capillary blood flow.

An alternative method of partitioning the ovarian arterial blood supply amongst the ovarian follicles (Brown et al., 1981), based on infusion of microspheres directly into the ovarian artery, was used in conjunction with the above technique. This method, while utilizing much smaller doses of microspheres, allows greater numbers of microspheres to reach the ovary and the ovarian follicles. It also enables simultaneous measurement of the proportion of arterial blood passing through ovarian arteriovenous anastomoses without the need to sample the ovarian venous drainage.

In brief, a known dose of microspheres of $15 \pm 3 \mu \mathrm{m}$ (mean \pm s.d.) diameter $\left(\sim 250 \times 10^{3}\right.$ per $\mathrm{kg}$ live weight and labelled with strontium-85 or cerium-14I: New England Nuclear Co., Dreieich, West Germany) was injected into the ventricular catheter of each ewe (label A) while blood was being withdrawn at about $20 \mathrm{ml} / \mathrm{min}$ from the femoral artery. During this injection, a second dose of $15 \mu \mathrm{m}$ diameter microspheres $\left(15-20 \times 10^{3}\right.$ microspheres in $0.4 \mathrm{ml}$ saline warmed to $37^{\circ} \mathrm{C}$ ), which contained a label (label B) different from that used for the ventricular dose, was injected through the ovarian side-branch catheter to allow assessments of ovarian follicular flow. 
Each ewe was then anaesthetized with pentobarbitone sodium and the ovary, the whole of the mesovarium ipsilateral to the ovary as well as the corresponding vascular pedicle, oviduct and anterior region of the ipsilateral uterine horn, were excised. The ovary was immediately weighed, placed in cold phosphate-buffered saline and its radioactive content determined in an autogamma spectrometer (Packard Instruments, La Grange, Illinois, USA: ${ }^{85} \mathrm{Sr}, 450$ $560 \mathrm{keV} ;{ }^{141} \mathrm{Ce}, 60-150 \mathrm{keV}$ ). For each ovary, follicles with a diameter of $1.0 \mathrm{~mm}$ or greater were removed by blunt dissection, placed in $10 \mathrm{ml}$ Bouin-Hollande's solution and counted in the same gamma counter, together with the other tissues (each of the other tissue were divided into sub-samples of $\sim 3 \mathrm{~g}$ ).

Histological preparation, classification and measurements of ovarian follicles. After fixation in Bouin-Hollande's solution, each follicle was serially sectioned at $10 \mu \mathrm{m}$. One section out of every 6 was mounted on a glass slide, stained with haematoxylin and examined microscopically to classify the follicle as being non-atretic (i.e. normal) or atretic (Driancourt et al., 1986)

For each follicle, the histological section with the largest outer diameter was used to obtain estimates of mean follicle diameter ( 2 measurements taken at right angles to each other) and mean thecal thickness ( 10 measurements at intervals around the theca, each taken from the outer edge of the theca to the basement membrane of the granulosa) and these values were used for the calculation of thecal volume.

Calculations and statistical analysis. Capillary blood flows $(\mathrm{ml} / \mathrm{min})$ in ovarian stroma $\left(\mathrm{Q}_{\mathrm{o}}\right)$ and ovarian follicles were calculated using the formula reported by Hales (1974). Ovarian blood flows were also calculated on a unit weight basis $(\mathrm{ml} / \mathrm{min} / 100 \mathrm{~g}$ ) while, for follicles, flows were expressed per unit volume of theca (see below), since measurement of ovarian thecal mass was impractical.

Estimates of capillary blood flow in individual follicles $\left(Q_{f}\right)$ were also calculated using the ratio of the counts per minute (c.p.m.) of label B in the follicle to that in the ovarian stroma, multiplied by the ovarian flow rate $\left(Q_{0}\right)$ obtained with label A. Thus:

$$
Q_{f}=\frac{\text { c.p.m. label B in follicle }}{\text { c.p.m. label B in stroma }} \times Q_{o}
$$

To enable comparisons to be made between follicles of different diameters and follicles with different ratios of tissue to antral fluid, the $\mathrm{Q}_{\mathrm{f}}$ values were divided by the corresponding estimate of thecal volume.

An assessment of the proportion of arterial blood passing through ovarian arterio-venous anastomoses (AVA) was obtained by calculating the percentage of $15 \mu \mathrm{m}$ diameter microspheres (label $\mathrm{B}$ ) that passed through the ovarian vasculature. Thus:

$$
\text { ovarian AVA flow }(\%)=\frac{\text { c.p.m. effective dose (label B) }- \text { c.p.m. label B in stroma }}{\text { c.p.m. effective dose (label B) }} \times 100
$$

where the effective dose of label B is the initial c.p.m. of label B in the dose syringe minus the c.p.m. of label B residue in (i) the dose syringe, (ii) the ovarian side-branch catheter and (iii) in other tissue (including the mesovarium, the ovarian vascular pedicle and the anterior region of the ipsilateral uterine horn).

The data were analysed using Student's $t$ test and regression analysis.

\section{Results}

At the time of tissue sampling (36-40 h after sponge removal), none of the ewes had ovulated and each ovary contained at least one large follicle of preovulatory size. Ovarian capillary blood flow values and estimates of the proportion (percentage) of blood flow passing through ovarian arteriovenous anastomoses in the two types of ewes are shown in Table 1. The mean ovarian capillary blood flow $\left(Q_{0}\right)$ value for the Préalpes ewes was not significantly different from that for the Romanov ewes. However, the percentage of flow passing through ovarian arterio-venous anastomoses differed significantly in the two types of ewes; values ranged from 10 to $91.6 \%$ in the Préalpes whilst the Romanovs had little or no anastomosal flow (Table 1). In Préalpes ewes, the percentage of ovarian anastomosal flow (log transformed values) was highly correlated with the level of $\mathrm{Q}_{\mathrm{o}}(\mathrm{ml} / \mathrm{min} / 100 \mathrm{~g}, r=-0.86, P<0.01, n=5)$.

In each breed, the mean ( \pm s.e.m.) follicular capillary blood flow values (for normal and atretic follicles) obtained with the ventricular (label A) and locally injected (label B) dose of microspheres did not differ significantly (Préalpes: $145.0 \pm 27 \cdot 3$ and $132.4 \pm 26.3(\mathrm{ml} / \mathrm{min}) \times 10^{4} / \mathrm{mm}^{3}$ respectively, $t=1 \cdot 265, P>0 \cdot 10, d f=27$; Romanovs: $271.5 \pm 38.8$ and $289.1 \pm 45.2$ respectively, $t=$ 1.2966, $P>0 \cdot 10, d f=23$ ). Additionally, the individual values obtained with the 2 methods in each type of ewe were highly correlated (Préalpes: $r=0.9319, P<0.001, n=28$; Romanovs: $r=$ 
Table 1. Ovarian stromal capillary blood flow rates, percentage (\%) of the total ovarian flow passing through ovarian arteriovenous anastomoses (AVA) and mean ( \pm s.e.m.) values in 5 Préalpes-du-Sud and 4 Romanov ewes near ovulation

\begin{tabular}{|c|c|c|c|c|c|c|c|}
\hline \multicolumn{4}{|c|}{ Préalpes-du-Sud } & \multicolumn{4}{|c|}{ Romanov } \\
\hline No. & $\mathrm{ml} / \mathrm{min}$ & $\mathrm{ml} / \mathrm{min} / 100 \mathrm{~g}$ & $\%$ AVA & No. & $\mathrm{ml} / \mathrm{min}$ & $\mathrm{ml} / \mathrm{min} / 100 \mathrm{~g}$ & $\%$ AVA \\
\hline 1 & 0.77 & $65 \cdot 0$ & $10 \cdot 0$ & 6 & 0.53 & 37.9 & 0 \\
\hline 2 & 0.78 & $55 \cdot 0$ & 33.9 & 7 & 0.45 & 37.4 & 0 \\
\hline 3 & 0.41 & $37 \cdot 4$ & $75 \cdot 7$ & 8 & 0.33 & $36 \cdot 4$ & 0 \\
\hline 4 & 0.52 & $34 \cdot 7$ & 90.0 & 9 & 0.39 & 19.6 & $1 \cdot 3$ \\
\hline 5 & $0 \cdot 13$ & $11 \cdot 8$ & $91 \cdot 6$ & & & & \\
\hline Mean & 0.52 & $40 \cdot 8$ & $60 \cdot 2$ & & 0.43 & $32 \cdot 8$ & $0 \cdot 3$ \\
\hline s.e.m. & $0 \cdot 12$ & $9 \cdot 2$ & $16 \cdot 3$ & & 0.04 & $4 \cdot 4$ & 0 \\
\hline
\end{tabular}

0.9593, $P<0.001, n=24$ ). Accordingly, follicular blood flow data shown in the tables were derived using label $\mathbf{B}$.

Mean estimates of ovarian follicular capillary blood flow $\left(Q_{f}\right)$ per unit thecal volume, together with various parameters of the ovarian follicles are shown in Table 2. In the Préalpes and Romanov ewes, the mean $Q_{\mathrm{f}}$ per unit volume of theca for normal follicles was significantly greater $(P<0.001)$ than the corresponding value for the atretic follicles (Table 2$)$. In the Romanov ewes, the mean $\mathrm{Q}_{\mathrm{f}}$ per unit volume of theca for normal follicles was significantly $(P<0.05)$ greater than that in the Préalpes but the mean values for the atretic follicles in the two breeds did not differ significantly (Table 2). For normal and atretic follicles, the mean follicle diameter, as well as the mean ratio of thecal volume to follicle diameter, did not differ in the 2 breeds.

Table 2. Mean ( \pm s.e.m.) follicular capillary blood flow $\left(Q_{f}\right)$ per unit thecal volume, diameter and the ratio of thecal volume to follicle diameter for normal and atretic ovarian follicles in 5 Préalpes-du-Sud and 4 Romanov ewes

\begin{tabular}{lcc}
\hline & Préalpes-du-Sud & Romanov \\
\hline Normal follicles & 14 & \\
No. $\geq 1 \cdot 0 \mathrm{~mm}$ diam. & $241 \cdot 3 \pm 30 \cdot 1$ & $* 365 \cdot 8 \pm 42 \cdot 4$ \\
$\mathrm{Q}_{\mathrm{f}}(\mathrm{ml} / \mathrm{min}) \times 10^{4} / \mathrm{mm}^{3}$ & $2 \cdot 9 \pm 0 \cdot 3$ & $3 \cdot 0 \pm 0 \cdot 2$ \\
Diameter $(\mathrm{mm}) \dagger$ & $0.26 \pm 0.03$ & $0 \cdot 25 \pm 0 \cdot 02$ \\
Thecal vol./follicle diam. & & \\
Atretic follicles & 14 & 5 \\
No. $\geq 1 \cdot 0 \mathrm{~mm} \mathrm{diam}$. & $23 \cdot 6 \pm 12 \cdot 0$ & $46 \cdot 4 \pm 23 \cdot 3$ \\
$\mathrm{Q}_{\mathrm{f}}(\mathrm{ml} / \mathrm{min}) \times 10^{4} / \mathrm{mm}^{3}$ & $1 \cdot 6 \pm 0 \cdot 1$ & $2 \cdot 2 \pm 0 \cdot 3$ \\
Diameter $(\mathrm{mm}) \dagger$ & $0 \cdot 18 \pm 0.02$ & $0 \cdot 19 \pm 0.02$ \\
Thecal vol./follicle diam. & \\
\hline
\end{tabular}

*Mean $\mathrm{Q}_{\mathrm{f}}$ values for normal follicles differed significantly, $P<0.05$.

$\dagger$ Estimates of follicle diameter obtained from histological sections.

The mean $Q_{f}$ values for normal follicles in Préalpes ewes increased sharply as follicle diameter increased from 1.0 to $7.0 \mathrm{~mm}$, whilst the mean $Q_{f}$ per unit thecal volume (see Table 3 ) remained fairly constant over the same diameter range. However, for equivalent follicles in the Romanovs, mean $Q_{f}$ increased markedly only over a follicle diameter range of 1.0 to $5.0 \mathrm{~mm}$, after which the blood flow rates plateaued. In contrast to the Préalpes ewes, $Q_{f}$ per unit thecal volume in Romanov 
ewes was elevated in small-sized follicles and decreased markedly with increasing follicle size (Table 3).

Table 3. Mean total capillary blood flow $\left((\mathrm{ml} / \mathrm{min}) \times 10^{4}\right)$ and mean capillary blood flow per unit volume of theca $\left((\mathrm{ml} / \mathrm{min}) \times 10^{4} / \mathrm{mm}^{3}\right)$ in normal ovarian follicles with different diameter size-range in 5 Préalpes-du-Sud and 4 Romanov ewes

\begin{tabular}{|c|c|c|c|c|}
\hline & \multicolumn{3}{|c|}{$\begin{array}{l}\text { Follicle diameter } \\
\text { size range }(\mathrm{mm})\end{array}$} & \multirow{2}{*}{$\begin{array}{l}\text { Mean no. of } \\
\text { follicles } \\
(3 \cdot 1-7.0 \mathrm{~mm}) / \text { ewe }\end{array}$} \\
\hline & $1 \cdot 0-3 \cdot 0$ & $3 \cdot 1-5 \cdot 0$ & $5 \cdot 1-7 \cdot 0$ & \\
\hline \multirow{4}{*}{$\begin{array}{l}\text { Préalpes } \\
\text { No. of follicles } \\
(\mathrm{ml} / \mathrm{min}) \times 10^{4} \\
(\mathrm{ml} / \mathrm{min}) \times 10^{4} / \mathrm{mm}^{3} \text { theca }\end{array}$} & & & & $1 \cdot 6$ \\
\hline & 6 & 5 & 3 & \\
\hline & $77 \cdot 3$ & 173.5 & $517 \cdot 3$ & \\
\hline & $268 \cdot 5$ & $196 \cdot 9$ & $260 \cdot 8$ & \\
\hline \multicolumn{4}{|l|}{ Romanov } & $3 \cdot 8$ \\
\hline No. of follicles & 4 & 10 & 5 & \\
\hline$(\mathrm{ml} / \mathrm{min}) \times 10^{4}$ & $115 \cdot 8$ & $313 \cdot 0$ & $310 \cdot 5$ & \\
\hline$(\mathrm{ml} / \mathrm{min}) \times 10^{4} / \mathrm{mm}^{3}$ theca & $521 \cdot 9$ & $384 \cdot 8$ & $202 \cdot 6$ & \\
\hline
\end{tabular}

\section{Discussion}

The similarity of the mean follicular capillary blood flow values and the high correlation existing between individual estimates obtained with the 2 methods indicates that the microspheres reaching the ovary via the systemic circulation and by direct infusion into the ovarian artery were distributed within the ovarian tissue in the same proportion. Moreover, this circumstance indicates that the microspheres administered using the latter technique were uniformally mixed with the ovarian arterial blood during passage through the ovarian vascular pedicle and, accordingly, these results validate the use of this procedure for measurement of ovarian follicular blood flows.

The present finding, that capillary blood flow per unit volume of theca for the normal follicle population as a whole was significantly greater in Romanov ewes than in low-ovulating Préalpes ewes, is in accord with earlier results in highly fecund Booroola and low fecund non-Booroola Merino ewes (Brown et al., 1981).

Grouping the normal follicles in this study into diameter size-ranges (Table 3) revealed that, in Romanov ewes, the mean capillary blood flow per unit volume of theca was greatest in smaller follicles (range 1.0-3.0 mm) and least in the larger follicles $(5 \cdot 1-7.0 \mathrm{~mm}$ ), whereas in the Préalpes, the corresponding mean flow values were similar across all follicle groupings. This finding may imply that, during the growth phase (up to $5.0 \mathrm{~mm}$ in diameter at least), ovarian follicles in Romanov ewes are perfused with a more efficient nutrient supply than those in Préalpes ewes. In addition, the elevated total capillary blood flow rate $(\mathrm{ml} / \mathrm{min})$ in small- and medium-sized normal follicles in the Romanov, may be important in facilitating the recruitment of greater numbers of follicles for development and maturation (Driancourt et al., 1986). Production of angiogenic factors by thecal (Makris et al., 1984) or granulosa (Koos, 1986) cells has been reported and fibroblast growth factor (FGF) is claimed to play a key role in ovarian angiogenesis (Gospodarowicz et al., 1985). Possibly a greater production of angiogenic substances such as FGF or a higher sensitivity of Romanov ovarian follicles to these substances may explain the higher capillary blood flow rate in the smaller-sized follicles in this breed.

In Romanov ewes, the lack of any further increase in total capillary blood flow between medium- $(3 \cdot 1-5 \cdot 0 \mathrm{~mm})$ and large-sized $(>5.0 \mathrm{~mm})$ follicles contrasts with the pattern observed in 
Préalpes ewes. Whether or not this steadily maintained follicular capillary blood flow rate over this follicle diameter range is a factor involved in the cause of reduced preovulatory follicle size in Romanov ewes (Driancourt et al., 1986) and other high fecund breeds such as the Booroola (Baird et al., 1982; Scaramuzzi \& Radford, 1983; Driancourt et al., 1985) and the Finnish Landrace (Webb \& Gauld, 1985) is not known.

The markedly reduced capillary blood flow rates for atretic follicles in Romanov and Préalpes ewes is in accord with earlier findings in Merino ewes (Brown et al., 1981) and with the finding that the thecal capillary network in sheep is significantly reduced as follicular atresia progresses (Hay et al., 1976). Further, little or no blood flow in atretic follicles is consistent with findings in rhesus monkeys that there is no uptake of labelled hCG by any follicle in the late luteal phase except the dominant follicle (Zeleznik et al., 1981), even though virtually every antral follicle possessed hCG binding sites. Comparable atretic follicles in sheep also possess binding sites for this hormone (Carson et al., 1979).

It is clear from results in Table 1 that total ovarian blood flow is greater in Préalpes than in Romanov ewes, since the ovaries in the former ewes have an anastomosal component to the total flow, in addition to the capillary component. Arterio-venous anastomoses have also been found in the ovaries of single ovulating strains of Merino ewes (Mattner et al., 1981) and the proportion of flow through these vessels was related to the presence or absence of corpora lutea. The finding that there was little or no ovarian anastomosal flow in Romanov ewes does not negate the occurrence of these structures in the ovary, but may simply indicate that they are not functional, at least at the preovulatory stage of the cycle. Nevertheless, these different circumstances controlling the distribution of the ovarian blood supply in Romanov and Préalpes ewes allow similar levels of stromal capillary blood flow in the 2 breeds. Whether these distribution mechanisms are also responsible for the different blood flow patterns in the normal follicle population in the 2 breeds is not known.

We thank the surgical staff at I.N.R.A., Nouzilly, for assistance; Miss A. L. Prieur and Dr R. Webb for dissection of the ovarian follicles; and Mrs M. Durand for technical assistance. This study was support by a grant from Services des Relations Internationales de l'I.N.R.A.

\section{References}

Baird, D.T., Ralph, M.M., Seamark, R.F., Amato, F. \& Bindon, B.M. (1982) Pre-ovulatory follicular activity and estrogen secretion of high (Booroola) and low fecundity Merino ewes. Proc. Aust. Soc. Reprod. Biol. 14, 83, Abstr.

Bindon, B.M. (1984) Reproductive biology of the Booroola Merino sheep. Aust. J. biol. Sci. 37, 163-189.

Bindon, B.M., Piper, L.R., Cummins, L.J., O'Shea, T., Hillard, M.A., Findlay, J.K. \& Robertson, D.M. (1985) Reproductive endocrinology of prolific sheep: studies of the Booroola Merino. In Genetics of Reproduction in Sheep, pp. 217-235. Eds R. B. Land \& D. W. Robinson. Butterworths, London.

Brown, B.W. \& Mattner, P.E. (1984) Effects of ovarian hormones on ovarian capillary blood flow in anoestrous ewes. Aust. J. biol. Sci. 37, 389-392.

Brown, B.W., Hales, J.R.S. \& Mattner, P.E. (1974) Capillary blood flow in sheep ovaries, measured by Iodoantipyrine and microsphere techniques. Experientia 30, 914-915.

Brown, B.W., Mattner, P.E. \& Bindon, B.M. (1981) Assessment of blood flow in individual ovarian follicles: Relative levels in ewes of high and low fecundity. Proc. Aust. Soc. Reprod. Biol. 13, 12, Abstr.
Cahill, L.P., Saumande, J., Ravault, J.P., Blanc, M., Thimonier, J., Mariana, J.C. \& Mauléon, P. (1981) Hormonal and follicular relationships in ewes of high and low ovulation rates. J. Reprod. Fert. 62, 141-150.

Carson, R.S., Findlay, J.K., Burger, H.G. \& Trounson, A.O. (1979) Gonadotropin receptors of the ovine ovarian follicle during follicular growth and atresia. Biol. Reprod. 21, 75-87.

Carson, R.S., Salamonsen, L.A. \& Findlay, J.K. (1986) Permeability of rat ovarian follicles to LH during development and luteinization. J. Reprod. Fert. 76, 663-676.

Driancourt, M.A., Cahill, L.P. \& Bindon, B.M. (1985) Ovarian follicular populations and preovulatory enlargement in Booroola and control Merino ewes. $J$. Reprod. Fert. 73, 93-107.

Driancourt, M.A., Gauld, I.K., Terqui, M. \& Webb, R. (1986) Variations in patterns of follicle development in prolific breeds of sheep. J. Reprod. Fert. 78, 565--575.

Driancourt, M.A., Philipon, P., Locatelli, A., Jacques, E. \& Webb, R. (1988) Are differences in FSH concentrations involved in the control of ovulation rate in Romanov and Ile-de-France ewes. J. Reprod. Fert. 83, 509-516. 
Findlay, J.K. \& Cummings, I.A. (1977) The effect of unilateral ovariectomy on plasma gonadotropin levels, estrus and ovulation rate in sheep. Biol. Reprod. 17, 178-183.

Fry, R.C., Clarke, I.J., Cummins, J.T., Bindon, B.M., Piper, L.R. \& Cahill, L.P. (1988) Induction of ovulation in chronically hypophysectomized ewes. $J$. Reprod. Fert. 82, $71 \mathrm{l}-715$.

Gospodarowicz, D., Cheng, J., Lui, G.M., Baird, A., Esch, F. \& Bohlen, P. (1985) Corpus luteum angiogenic factor is related to fibroblast growth factor. Endocrinology 117, 2383-2391.

Hales, J.R.S. (1974) Radioactive microsphere techniques for studies of the circulation. Clin. exp. Pharmac. Physiol. Suppl. 1, 31-46.

Hay, M.F., Cran, D.G. \& Moor, R.M. (1976) Structural changes occurring during atresia in sheep ovarian follicles. Cell Tiss. Res. 169, 515-529.

Koos, R.D. (1986) Stimulation of endothelial cell proliferation by granulosa cell-conditioned medium. Endocrinology 119, 481-489.

Lahlou-Kassi, A., Schams, D. \& Glatzel, P. (1984) Plasma gonadotrophin concentrations during the oestrous cycle and after ovariectomy in two breeds of sheep with low and high fecundity. $J$. Reprod. Fert. 70, $165-173$.

Land, R.B., Pelletier, J., Thimonier, J. \& Mauléon, P. (1973) A quantitative study of genetic differences in the incidence of oestrus, ovulation and plasma luteinizing hormone concentration in the sheep. $J$. Endocr. 58, 305-317.

Makris, A., Ryan, K.J., Yasumizu, T., Hill, C.L. \& Zetter, B.R. (1984) The nonluteal porcine ovary as a source of angiogenic activity. Endocrinology 115, $1672-1677$.

Mattner, P.E., Brown, B.W. \& Hales, J.R.S. (1981) Evidence for functional arterio-venous anastomoses in the ovaries of sheep. J. Reprod. Fert. 63, $279-284$.

MeNatty, K.P., Hudson, N., Henderson, K.M., Gibb, M., Morrison, L., Ball, K. \& Smith, P. (1987) Differences in gonadotrophin concentrations and pituitary responsiveness to $\mathrm{GnRH}$ between Booroola ewes which were homozygous (FF), heterozygous $(F+)$ and non-carriers $(++)$ of a major gene influencing their ovulation rate. J. Reprod. Fert. 80, 577-588.

Scaramuzzi, R.J. \& Radford, H.M. (1983) Factors regulating ovulation rate in the ewe. J. Reprod. Fert. 69, 353-367.

Webb, R. \& England, B.G. (1982) Identification of the ovulatory follicle in the ewe: associated changes in follicular size, thecal and granulosa cell luteinizing hormone receptors, antral fluid steroids, and circulating hormones during the preovulatory period. Endocrinology 110, 873-881.

Webb, R. \& Gauld, I.K. (1985) Folliculogenesis in sheep: control of ovulation rate. In Genetics of Reproduction in Sheep, pp. 261-270. Eds R. B. Land \& D. W. Robinson. Butterworths, London.

Zeleznik, A.J., Schuler, H. M. \& Reichert, L.E. (1981) Gonadotropin-binding sites in the Rhesus Monkey ovary: role of the vasculature in the selective distribution of human chorionic gonadotropin to the preovulatory follicle. Endocrinology 109, 356-362.

Received 27 June 1988 